\title{
ХАРАКТЕРИСТИКА НЕКОТОРЫХ ЭЛЕМЕНТОВ РОДИЛЬНО-КРЕСТИЛЬНОЙ ОБРЯДНОСТИ ГРЕКОВ КРЫМА И ПРИАЗОВЬЯ (КОНЕЦ ХІХ - XX ВВ.)
}

\section{CHARACTERISTIC OF SOME ELEMENTS OF MATERNITY AND BAPTISMAL RITUALS OF THE GREEKS OF CRIMEA AND PRIAZOVIA (END OF THE XIX - XX CENTURIES)}

V. Dmitrieva

Summary: The article considers a number of elements of the maternity and baptismal rites of the Greeks of the Crimea and the Sea of Azov. The rites and traditions of the maternity and baptismal rites of the Crimean and Azov Greeks and the peoples of the Crimea, Turkey, Southeast Europe are compared. The traditional folk remedies for infertility are described in detail, their classification is given. Information is given about the complex of charms that were used to protect against the evil eye and the effects of evil spirits, both of the newborn and woman in labor. The role of the midwife in the maternity and baptismal rites of the Greeks of the Crimea and the Sea of Azov is determined.

Keywords: maternity and baptismal rites, Crimean Greeks, Azov Greeks, infertility, parturient mother, newborn, midwife.

\author{
Дмитриева Виктория Викторовна \\ К.и.н., дочент, ФГАОУ ВО «Севастопольский \\ государственный университет» \\ viktoriadmitrieva2010@mail.ru
}

Аннотация: В статье рассмотрены ряд элементов родильно-крестильной обрядности греков Крыма и Приазовья. Сравниваются обряды и традиции родильно-крестильной обрядности крымских и приазовских греков и народов Крыма, Турции, Юго-Восточной Европы. Подробно описаны традиционные народные средства лечения бесплодия, дана их классификация. Приводится информация о комплексе оберегов, которые использовались для защиты от сглаза и действия нечистой силы, как новорожденного, так и роженицы. Определена роль повитухи в родильно-крестильной обрядности греков Крыма и Приазовья.

Ключевые слова: родильно-крестильная обрядность, крымские греки, приазовские греки, бесплодие, роженица, новорожденный, повитуха.
$\mathrm{O}$ дним из народов, которые с древних времен проживают в Крыму, являются греки. В 1778 - 1780 гг. крымские греки были переселены с территории полуострова в Приазовье и получили название в этнографической литературе «приазовские греки». На данный момент в составе этноса существуют две этнографические группы, выделяемые исследователями по языковому признаку: румеи, говорящие на диалектах крымскорумейского языка (близок к новогреческому) и урумы, чей язык схож с крымскотатарским (Араджиони М.А. Греки Крыма и Приазовья: история изучения и историография этнической истории (80-е гг. XVIII - 90-е гг. XX в.). Симферополь, 1999. С.6).

Составной частью семейной обрядности греков Крыма и Приазовья является родильно-крестильная обрядность. В статье дается характеристика некоторых элементов родильно-крестильной обрядности крымских и приазовских греков и приводится информация, которая была получена по данной проблематике во время Приазовских фольклорно-этнографических экспедиций (ПФЭЭ), организованных Крымским отделением Института востоковедения им. А. Крымского НАН Украины в 2010, 2011, 2012 гг. $(10,11,12)$.
У крымских и приазовских греков бездетность “есенкам" у румеев (рум.), "хисырк" у урумов (урум.) считали самым большим несчастьем для семьи. Об этом свидетельствуют этнографические источники, народные пословицы и поговорки, информация респондентов ПФЭЭ.

Также известно, что до рождения ребенка молодую женщину не считали полноправным членом семьи - на нее распространялись обычаи «избегания» (она не могла разговаривать с родителями и другими старшими родственниками мужа до пяти лет со дня свадьбы), ей приходилось выполнять самую тяжелую работу по хозяйству (Ксенофонтова-Петренко О.Н. Семейные обряды в селе Сартана. М.: Наука, 1979. С.175).

Бездетные гречанки не теряли надежду излечиться от бесплодия, прибегали к использованию различных средств народной медицины, выполняли ритуалы и обряды, обращались за помощью к божественным силам, посещали языческие святыни. Материалы ПФЭЭ являются главным источником по данной проблеме, поскольку В этнографической литературе XVIII - начала XXI вB. она практически отсутствует из-за своей интимности и деликатности. 
Все зафиксированные в ходе экспедиций народные средства лечения от бесплодия гречанок Крыма и Приазовья, были разделены на три группы:

1. средства и методы народной медицины (их применяли знахарки и повитухи);

2. посещение христианских святынь;

3. почитание святых мест, которые имеют языческую или языческо-христианскую природу.

Во время второй ПФЭЭ респонденты рассказывали, что женщины, которые хотели излечиться от бесплодия, часто обращались за помощью к знахаркам. В урумском селе Богатырь их называли - «бахтаджи хачлай» (ПФЭЭ. Часть 2. Л.28). Знахарки использовали иррациональные методы лечения от бесплодия: заговоры, чтение молитв и рациональные средства: лекарственные отвары, горячие молочные ванны. Из этнографической литературы известно, что те же средства применяли знахарки и повитухи у крымских татар, турок, гагаузов, болгар, албанцев. Например, болгарские знахарки чаще всего использовали отвары из трав и заговоры (Маркова Л.В. Болгары. М.: Наука, 1999. С.108; Музыченко А.Ф. Первые годы детства у болгар. СПб., 1903. С.21), албанские врачевательницы - прогревали тело и делали массажи (Иванова Ю.В. Албанцы. М.: Наука, 1999. С.145), у крымских татар знахарки применяли массажи и горячие ванны (Полевые материалы по родильной обрядности крымских татар. Полевая тетрадь (п/т) № 1. Л.6). У турецких знахарок, как и у греческих, главными средствами были ванны из молока или отваров лекарственных трав, также они советовали бездетным женщинам посетить горячие источники, не переохлаждаться, стараться держать ноги в тепле (Серебрякова М.Н. Семейная обрядность в турецкой деревне. М.: Наука, 1979. С.165).

Во время первой и третьей ПФЭЭ респонденты рассказывали о том, бездетные женщины часто посещали храмы, такие как церковь Рождества Богородицы, Успенскую церковь (в ней находилась особо почитаемая икона Божьей Матери - Одигитрии). У этой иконы, которая считалась чудотворной, просили исцеления не только крымские христианки, но и татарки (Попов А.Н. Вторая учебная экскурсия симферопольской мужской гимназии в Бахчисарай и его окрестности. Симферополь, 1999. С.77-78). При переселении греков на территорию Приазовья эта икона была перевезена и помещена в одной из церквей Мариуполя.

Бездетные приазовские гречанки в церкви перед иконой давали священный обет, в случае своего исцеления, пожертвовать деньги на нужды храма, помогать больным и нищим.

Третью группу составляют методы, связанные с посещением святых мест, имеющих христианско-языческую природу. В Крыму такими чудодейственными местами были горные источники рядом с церквями или на территории монастырей. Например, источник святой Анастасии рядом с одноименной церковью на территории Качи-Кальона. М. Протопопов писал о том, что большая часть церквей и монастырей в Крыму были основаны, как и церковь святой Анастасии, вблизи горных источников (Протопопов М. Чуфут-Кале, Тепе-Кермен, монастырь Святой Анастасии и Качи-Кальон. Севастополь, 1905. C.26).

Рядом с источником находилось дерево черешни, которое наделялось чудодейственными свойствами. Женщины привязывали к нему лоскутки своей одежды, чтобы исцелиться от бесплодия и других болезней. Эти своеобразные жертвоприношения совершали те только гречанки, но и крымские татарки (Веймарн Е., Чореф М. Корабль на Каче. Симферополь, 1976. С.28).

Вся вышеизложенная информация позволяет сделать вывод, что в традиционной культуре крымских и приазовских греков, как и крымских татар, с которыми греки имели тесные межэтнические контакты в крымский период своей истории, присутствуют многие пережитки языческих культов и верований - поклонение водным источникам и деревьям, вера в их чудодейственные свойства. Отметим также, что бездетные гречанки и представительницы ряда других народов Крыма искали исцеления в поклонении только плодовым деревьям, т.е., в данном случае переплелись приемы контактной и имитативной магии.

Прослеживается параллель между действиями гречанок и крымских татарок, турчанок - вера в сверхъестественные силы отдельных предметов и вещей (источников, деревьев) - фетишизм, а также обращение за помощью к знахаркам. Кроме того, существовали и локальные методы и средства исцеления от бесплодия: у мусульман (турок, татар) - это было посещение могил святых «мезаров», использование амулетов, изготовленных муллой; а у христиан (греки Крыма и Приазовья, болгары, албанцы) - обращение к Пресвятой Богородице, молитвы в церкви, материальная помощь храмам. Все перечисленные средства связаны с тем, какую религию исповедует народ, элементы родильной обрядности которого изучаются.

У греков семьи без детей считались неполноценными. Поэтому люди, у которых по разным причинам не было своих детей, часто усыновляли чужих (преимущественно мальчиков), чаще всего сирот. Были случаи, когда многодетные родственники отдавали одного из своих детей на воспитание в бездетную семью. Довольно часто в документах в качестве «некровных детей» встречается такая категория, как «воспитанники». Данный факт наводит на мысль о существовании у греков института аталычества. 
Подобный институт бытовал у многих народов Крыма и Кавказа, в частности, и у крымских татар. Так, известно, что у них было принято новорожденных детей отдавать на попечение кормильцу - «аталыку», у которого ребенок воспитывался до 7 - 8-летнего возраста. Как и дети простых татар, сыновья и дочери крымских ханов воспитывались также вне стен родного дома (Косвен М.О. Аталычество. С. 10).

Не следует забывать о том уважении, с которым относились греки Крыма и Приазовья к аталыкам, крестным родителям своих детей. В народе даже говорили: «Чем больше у тебя крестников, тем больше грехов простит тебе Господь» (ПФЭЭ. Часть 3. С.77).

Греки Крыма и Приазовья считали, что бездетная женщина, которая использовала средства и методы народной медицины, молилась Богу, посещала святые места, брала на воспитание чужих детей, должна вылечиться и стать способной рожать. В психологическом плане подобного рода средства, действительно, положительно влияли на женщину, она начинала верить в свое исцеление, но в медицинском плане это редко когда приводило к положительным результатам, то есть к излечению.

Беременная женщина («сустрата» - рум., «устабар» урум.) у греков Приазовья была наделена особым статусом, окружена заботой и вниманием. В народе говорили: «Во время беременности у женщины две души» (ПФЭЭ. Часть 3. С.38-46). Перед родами женщина должна была помолиться в церкви, помириться со всеми, с кем была в ссоре. Когда начинались схватки, согласно обычаю, муж сам шел звать повитуху. У крымских и приазовских греков было принято звать к роженице ту повитуху, которая уже принимала роды в этой семье. Повитухи («манака» - рум., «бекана» - урум.), как и роженицы, у греков имели особый статус и имели возрастные и функциональные ограничения. Повитухой могла быть женщина среднего или пожилого возраста, которая ранее сама рожала (ПФЭЭ. Часть 3. С.47).

Кроме принятия родов, в обязанности повитухи входил уход за роженицей и новорожденным в первые дни послеродового периода, а также она руководила обрядами, которые способствовали социализации ребенка - помогала в организации «Панаяс трапез» (рум.) (Ксенофонтова-Петренко О.Н. Семейные обряды в селе Сартана. С.182)., «Панаяс софра» (урум.) (Марков С.И. Заметки о быте греков г. Мариуполя. Мариуполь, 1892. С.431) «Стол Божьей Матери», ходила в церковь за именем новорожденному, давала советы по организации крестин, сопровождала роженицу в храм за молитвой на 41-й день после родов.

В этнографической литературе информация об оберегах, которые использовались для защиты от сглаза и «нечистой силы» новорожденного и роженицы в родильной обрядности греков Крыма и Приазовья фрагментарна. Зафиксированные в период ПФЭЭ обереги условно разделены на пять групп, это:

- изделия из металла (ножницы, булавка, иголка, медные или свинцовые амулеты);

- лекарственные травы (чабрец, бессмертник);

- предметы быта (веник);

- продукты (хлеб, соль);

- ткани, украшения (одежда навыворот, голубая или синяя бусина).

Изделия из металла - это, как правило, булавка, иголка и ножницы. Булавку прикалывали к одежде младенца и роженицы; ножницы и иголку прятали под подушку. Из статьи В.И. Шевченко известно, что мариупольские греки изготавливали из меди или свинца амулеты, по форме напоминающие тот орган человеческого тела, который болел (Шевченко В.И. Древние верования и обряды в греческих колониях. 1927. С.11). Эти амулеты также использовали, чтобы защитить роженицу и новорожденного от сглаза, носили их на тесьме, повязав вокруг шеи. Интересно, что хранили эти обереги в церкви, а при необходимости брали в пользование, возвращали же после исцеления вместе со старым, новый экземпляр, который изготавливали своими руками.

Можно выдвинуть предположение, что металлические амулеты греков Приазовья в форме отдельных органов человека - головы, уха, сердца, глаза, руки, ноги - это одна из форм культа святых мощей.

Отметим, что у румелийских (фракийских) греков (например, в селе Лаганда в Северной Греции и в селе Чернополье в Крыму) и в наши дни применяются амулеты похожие на вышеописанные приазовские (Араджиони М.А. Греки Крыма и Приазовья. С.110). Их прикрепляли к вышитым полотенцам, которые обрамляли иконы и хранили в церкви, а если храма в селе не было - тогда в доме самого пожилого и уважаемого односельчанина

В качестве оберега греки Крыма и Приазовья также использовали лекарственные травы. Этот обычай сохранен до сих пор греками сел Улаклы, Богатырь, Комар (Камара), Старомлиновка (Керменчик), Великая Новоселка (Аргин Ени-сала). Все они, за исключением Великой Новоселки (здесь население смешанное: урумы и румеи), были основаны греками-урумами, переселившимися в Приазовье из юго-западного Крыма.

Лекарственные травы либо прятали под подушку, либо тайно зашивали в одежду ребенка. В большинстве случаев использовали бессмертник - «титутрун чичек» (с. Великая Новоселка) и чабрец - «назар чичек» (с. Старомлиновка, Улаклы, Комар, Богатырь). С помощью лекарственных трав оберегали от сглаза новорожденного 
и роженицу и крымские татары (Энвер Ш. Доисламские религиозно-культовые представления. С.8).

У греков Крыма и Приазовья в качестве оберега использовали веник («себерже» - урум., «фкал» - рум.). Его называли «охранником», поскольку в то время, когда мать выходила из комнаты, веник ставили рядом с колыбелью новорожденного на «страже его от нечистой силы».

Не только греки, но и многие кавказские народы, восточные и южные славяне, болгары и многие другие народы Европы и Азии приписывали венику магические свойства. Обычай применения веника в качестве оберега имеет широкий ареал, что усложняет процесс определения места и времени его возникновения.

В конце XIX века у крымских и приазовских греков существовал ритуал с использованием хлеба. На 40-ой день после родов роженица с младенцем и повитухой ходили в церкви. Когда они оттуда возвращались домой, на пороге их должна была ожидать крестная мать новорожденного. Она клала кусочек хлеба, обожженного на свече, в одеяльце ребенка и говорила: «Будь белый, как сахар (т.е., проживи до седых волос) и добрый, как хлеб» (Ксенофонтова-Петренко О.Н. Семейные обряды в селе Сартана. С.182; Марков С.И. Заметки о быте греков г. Мариуполя. Мариуполь (.415). После этот кусочек хлеба всегда находился в одеяле младенца и выступал в роли оберега от сглаза и защиты от нечистой силы и разных болезней.

Наши респонденты рассказывали, что кусочек хлеба прятали не только в одеяло младенца, но и под подушку, как и обереги из металла, лекарственные травы. Вероятно, это новая форма обычая, который существовал в конце XIX века и был описан С.И. Марковым и О.Н. Ксенофонтовой-Петренко $(5,6)$.

Культ зерна и хлеб и в наши дни широко распространен не только в родильной, но и свадебной, погребально-поминальной обрядности греков Приазовья (ПФЭЭ. Часть 2. Л. 7,12) и многих других народов. В языческий период хлеб выступал предметом жертвоприношений, в условиях современности он является в представлениях людей символом богатства, долголетия, плодородия. Поэтому не случайно ему приписывают и функции оберега.

Кроме хлеба в качестве оберега использовали соль. Она лишь условно может быть отнесена к оберегам, поскольку многие народов Европы и Азии (в том числе греки Приазовья) использовали ее и как антисептик в условиях жаркого климата.

Респонденты из сел Старый Крым, Первомайское (Мангуш), Раздольное (Аргин Кара-коба) говорили, что соль добавляли в воду для купания новорожденного, «чтобы ребенок меньше потел» (ПФЭЭ. Часть 1. Л.9; ПФЭЭ. Часть 3. Л.8, 27). Во время полевых работ в Крыму был зафиксирован обычай купания ребенка в соленой воде у крымских татар ((Полевые материалы по родильной обрядности крымских татар. С.4). О добавлении соли в воду для купания ребенка пишет в своей работе Г. Боплан: «татарки день в день купают новорожденного в воде с солью» (Энвер Ш. Доисламские религиозно-культовые представления. С.9).

В селах Стыла, Гранитное (Карань), Комар (Камара), Раздольное (Аргин Кара-коба), Богатырь проводили обряд посыпания солью тела новорожденного (ПФЭЭ. Часть 2. Л.3, 13. 21, 28). Таким же образом поступали повитухи у турок (Серебрякова М.Н. Семья и семейная обрядность в турецкой деревне. С.131).

В селе Великая Новоселка (Аргин Ени-сала) респонденты рассказывали, что соль и мак сыпали во всех углах детской комнаты в начале недели - по понедельникам, чтобы очистить ее от действия «нечистой силы» (ПФЭЭ. Часть 2. Л.25).

А вот такой оберег как синяя бусинка применяли только в урумских селах, таких как Ласпи, Гранитное (Карань), Богатырь, Комар (Камара), Старомлиновка (Керменчик). Синюю бусину подвешивали к одежде ребенка. Черная или синяя бусина с белым кружочком посередине («гуз бунджах») остается оберегом у крымских татар (Энвер Ш. Доисламские религиозно-культовые представления. С.9), турок (Серебрякова М.Н. Семья и семейная обрядность в турецкой деревне. С.133). Такие бусины нанизывают на шнурок и одевают на руку детям.

Возможно, использование синей бусины в качестве оберега, урумы могли перенять у крымских татар, испытав влияние пережитков доисламских традиций этого народа на свою культуру. Поскольку, проживая в югозападной части Крымского полуострова, урумы более тесно взаимодействовали с крымскими татарами, чем румеи.

Обереговый комплекс приазовских греков сохранился не полностью, некоторые его элементы утратили свое первоначальное значение. Большая часть оберегов, которые дошли до наших дней и используются и сейчас (изделия из железа, хлеб, соль, вода) связаны с дохристианскими религиозными представлениями и свидетельствует о древности их происхождения.

Выявленные расхождения в оберегах урумов и румеев (лекарственные травы, синяя бусина, повязка на руку из разноцветных нитей) обусловлены не столько разницей их этнического происхождения, сколько степенью интенсивности этнокультурных контактов, что во мно- 
гом связано с локализацией этих этнографических групп на территории Крыма и Приазовья.

Подводя итоги, отметим, что перечисленные в статье элементы родильно-крестильной обрядности греков
Крыма и Приазовья находят прямые аналогии в родильной обрядности крымских татар, турок, болгар, албанцев. Это может свидетельствовать о взаимовлиянии и тесных межэтнических контактах греков и данных этносов в разные исторические периоды.

\section{ЛИТЕРАТУРА}

1. Араджиони М.А. Греки Крыма и Приазовья: история изучения и историография этнической истории (80-е гг. XVIII - 90-е гг. XX в.). Симферополь: Издательский Дом «Амена», 1999. 132 с.

2. Веймарн Е., Чореф М. Корабль на Каче. Симферополь: Таврия, 1976. 81 с.

3. Иванова Ю.В. Албанцы // Рождение ребенка в обычаях и обрядах. Страны зарубежной Европы. М.: Наука, 1999. - С.141-161.

4. Косвен М.0. Аталычество // Советская этнография. 1935. №11. С.3-46.

5. Ксенофонтова-Петренко 0.Н. Семейный обряды в селе Сартана // Культурно-бытовые процессы на юге Украины. М.: Наука, 1979. С.173- 185.

6. Марков С.И. Заметки о быте греков г. Мариуполя // Мариуполь и его окрестности. - Мариуполь, 1892. С.406-438.

7. Маркова Л.В. Болгары // Рождение ребенка в обычаях и обрядах. Страны зарубежной Европы. М.: Наука, 1999. С.98-124.

8. Музыченко А.Ф. Первые годы детства у болгар // Известия Санкт-Петербургского славянского благотворительного 0бщества. СПб., 1903. С18-27.

9. Полевые материалы по родильной обрядности крымских татар 2010г. // Личный архив автора. Полевая тетрадь (п./т.) №1. Л.1-7.

10. Полевые материалы по семейной обрядности греков Приазовья. Часть $1 / /$ Архив Крымского отделения Института востоковедения. Ф. Приазовской фольклорно-этнографической экспедиции (Ф. ПФЭЭ). П./т. № 7/1. Л.2-80.

11. Полевые материалы по семейной обрядности греков Приазовья. Часть 2 // Архив Крымского отделения Института востоковедения. Ф. ПФээ. П./т.№1/1. Л.7-77; П./т. №1/2 Л.4-43.

12. Полевые материалы по семейной обрядности греков Приазовья. Часть 3. // Архив Крымского отделения Института востоковедения. Ф. ПФэЭ. П./т. №1. Л.3-30.

13. Попов А.Н. Вторая учебная экскурсия симферопольской мужской гимназии в Бахчисарай и его окрестности. Симферополь, 1888. 131 с.

14. Протопопов М. Чуфут-Кале, Тепе-Кермен, монастырь Святой Анастасии и Качи-Кальон, близ Бахчисарая. Севастополь, 1905. 35 с.

15. Серебрякова М.Н. Семья и семейная обрядность в турецкой деревне. М.: Наука, 1979. 166 с.

16. Шевченко В.И. Древние верования и обряды в греческих колониях // Наука и техника. 1927. № 52. С.11.

17. Энвер Ш. Доисламские религиозно-культовые представления, сохранившиеся в семейном быту крымтатар // Къасевет. 1989. №2/17. С.8-9.

(с Дмитриева Виктория Викторовна (viktoriadmitrieva2010@mail.ru).

Журнал «Современная наука: актуальные проблемы теории и практики»

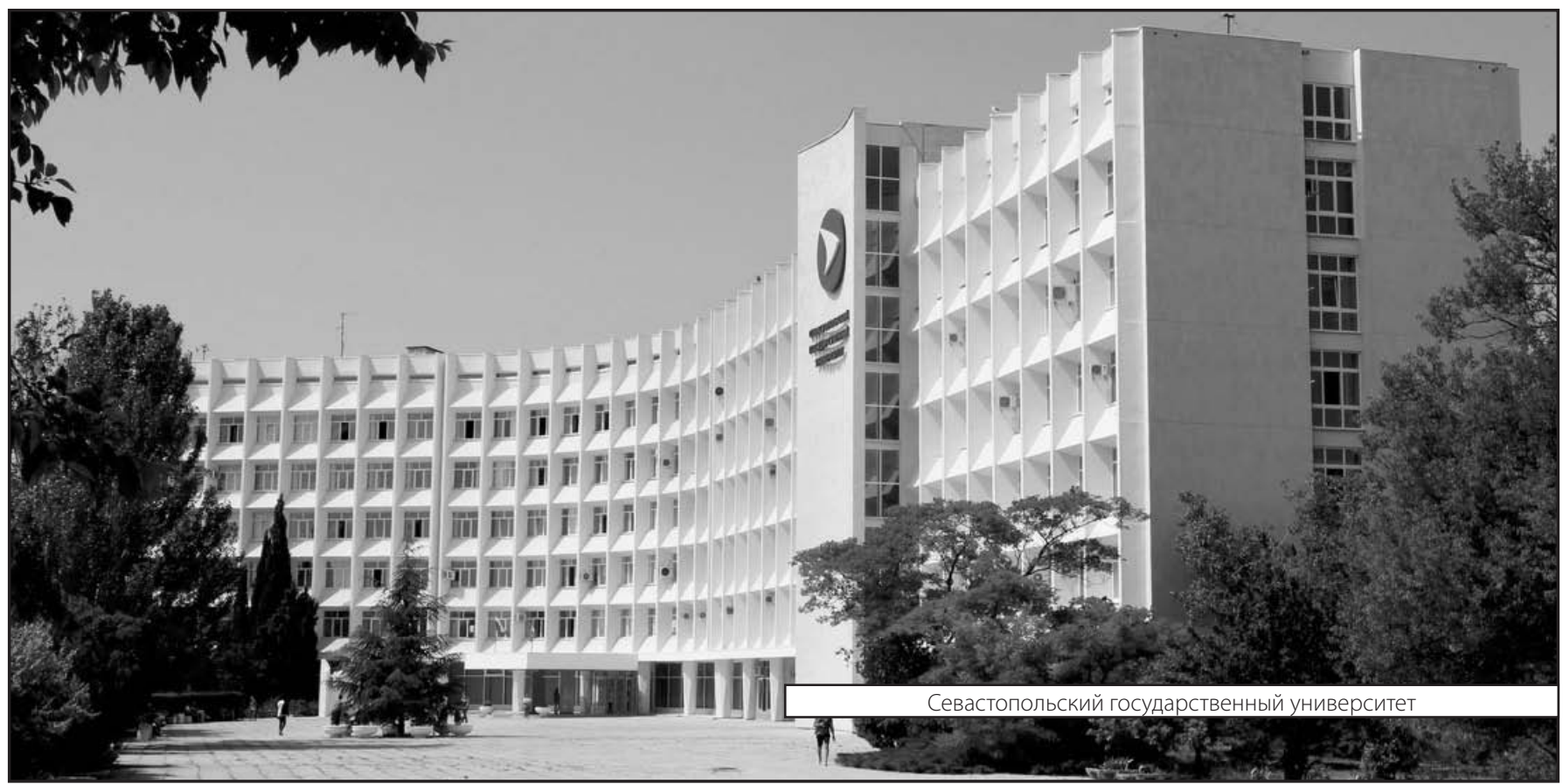

